\title{
EVALUASI TUTUPAN LAHAN DAN EFEKTIVITAS PENGELOLAAN KAWASAN TAMAN WISATA ALAM BUKIT KABA PROVINSI BENGKULU
}

\author{
Silvia Alparisi ${ }^{1)}$, Wiryono $^{2)}$, Enggar Aprianto ${ }^{2)}$ \\ ${ }^{1)}$ Mahasiswa Program Pascasarjana Pengelolaan Sumberdaya Alam UNIB \\ ${ }^{2)}$ Jurusan Kehutanan Fakultas Pertanian Universitas Bengkulu
}

\begin{abstract}
ABSTRAK
Survey yang konperensif mengenai Evaluasi Tutupan Lahan dan Efektifitas Pengelolaan di kawasan Taman Wisata Alam Bukit Kaba pada dasarnya belum pernah dilakukan. Tujuan dari penelitian ini adalah untuk mengatahui kondisi Tutupan Lahan dan Efektivitas Pengelolaan. Penelitian dilakukan dengan Metode METT, ArcGis, dan Groundcheck di lapangan. Hasil Penelitian dengan menggunakan METT menunjukkan bahwa kawasan TWA Bukit Kaba memiliki nilai Efektivitas tinggi dengan perolehan persentase rata-rata $80 \%$ dari hasil penilaian efektivitas pengelolaan secara keseluruhan dinyatakan Sangat Efektif. Namun hasil evalusi tutupan lahan dan Groundcheck di lapangan menunjukkan keadaan yang sebaliknya dari hasil METT yang di peroleh, dengan kata lain hasil evaluasi dan pengamatan dilapangan TWA Bukit kaba menunjukkan bahwa pengelolaan yang dilakukan belum efektif secara keseluruhan.
\end{abstract}

Kata Kunci : taman wisata alam, bukit kaba, tutupan lahan, efektivitas pengelolaan

\section{PENDAHULUAN}

Indonesia sudah banyak ditetapkan Taman Wisata Alam, mulai dari Aceh hingga Papua tersebar sekitar 115 Taman Wisata Alam diseluruh indonesia. Salah satu dianaranya adalah Taman Wisata Alam Bukit Kaba. Survey yang konperensif mengenai Evaluasi Tutupan Lahan dan Efektifitas Pengelolaan di kawasan Taman Wisata Alam Bukit Kaba pada dasarnya belum pernah dilakukan oleh mahasiswa program studi Pascasarjana Pengelolaan Sumberdaya Alam Dan Lingkungan Fakultas Pertania Universitas Bengkulu. Permasalahan yang umum terjadi dalam pengelolaan adalah adanya kesulitan untuk mengidentifikasi prioritas permasalahan, kurangnya sumberdaya yang tersedia, ketidak tepatan dalam dalam mengalokasikan sumber daya yang dimiliki, serta belum diketahui sejauh mana pengelolaan yang dilakukan berada dalam arah yang benar dalam mencapai tujuan pengelolaan yang sesungguhnya.

Hasil penelusuran tersebut perlu diadakan Evaluasi Tutupan Lahan dan Efektivitas Pengelolaan Kawasan TWA Bukit Kaba secara konferensif untuk mengetahui perubahan yang terjadi pada tutupan lahan TWA Bukit Kaba dan pengelolaan kawasan Taman Wisata Alam Bukit Kaba tersebut. Tujuan dari penelitian ini adalah untuk mengetahui kondisi tutupan lahan dan mengetahui tingkat efektivitas pengelolaan kawasan TWA Bukit Kaba. Wisata alam adalah bentuk kegiatan rekreasi dan pariwisata yang memanfaatkan potensi sumberdaya alam, baik dalam keadaan alami maupun setelah ada usaha budidaya, sehingga memungkinkan wisatawan memperoleh kesegaran jasmaniah dan rohaniah, mendapatkan pengetahuan dan pengalaman serta menumbuhkan inspirasi dan cinta terhadap alam (Saragih, 1993). 
Taman Wisata Alam merupakan tempat yang sesuai untuk proses pembelajaran bagi semua umur. Selain belajar tentang alam, di sini juga bisa di adakan kegiatan outbond yang melatih kerjasama, kebersamaan, kepemimpinan dan soft skill lain yang dibutuhkan manusia sebagai makhluk sosial. Jika kegiatan tersebut dilakukan oleh sebuah keluarga maka akan mempererat rasa memiliki dan kekeluargaan antar anggota keluarga. (Fandeli. C. 2007).

Metode METT merupakan metode penilaian secara cepat berdasarkan pendapat ahli. Karakteristik metode penilaian ini yaitu cepat, murah dan mudah, dilaksanakan melalui kuisioner dan wawancara kepada pengelola kawasan, menggunakan sistem scoring, dapat melacak perkembangan setiap waktu (Wardhana, 2015).

\section{METODE PENELITIAN}

Penelitian ini dilaksanakan pada bulan Juli-Sepetember 2016 (Observasi Lapangan) di Kawasan Taman Wisata Alam Bukit Kaba (Kecamatan Selupu Rejang Kabupaten Rejang Lebong Propinsi Bengkulu), Desember 2016 - Juni 2017 (Olah Data Lapangan dan Pengumpulan Literatur).

Adapun variable yang di amati dalam penelitian ini adah SHP tutupan lahan TWA Bukit Kaba, Citra Landsat 8 dan Efektivitas Pengelolaan TWA Bukit Kaba secara Kelembagaan. Untuk memperoleh data dilakukan terlebih dahulu mengajukan permohonan diterbitkannya SHP tutupan lahan TWA Bukit Kaba, Adapun tahapan dalam analisis besaran perubahan tutupan lahaan TWA Bukit Kaba yaitu : Mengajukan permohonan data SHP tutupan lahan TWA Bukit Kaba dari Tahun 2014, 2015 dan 2016 diolah menjadi peta tutupan lahan menggunakan aplikasi ArcGis. selanjutnya meng unduh data Citra Landsat 8 melalui Web Gis USGS (United States Geological Survey), dilanjutkan dngan Groundcheck Point di lapangan. Dari hasil olahan data tersebut akan disajikan hasil berupa peta dan persentase perubahan tutupan lahan dalam rentang waktu 2014, 2015 - 2016. Efektivitas pengelolaan kawasan TWA Bukit Kaba di analisis dengan Metode Effectiveness Tracking Tool (METT) yang hasilnya di ulas dalam bentuk persentase (\%). Untuk memperoleh persentase efektifitas pengelolaan dapat dihitung dengan rumus :

$$
\begin{aligned}
& \text { Efektifitas Pengelolaan (\%) } \\
& =\frac{\text { Skor Penelitian }}{\text { Total Skor }} \times 100 \%
\end{aligned}
$$

\section{HASIL DAN PEMBAHASAN}

\section{Efektivitas Pengelolaan}

Efektivitas menunjukkan keberhasilan dari segi tercapai tidaknya sasaran yang telah ditetapkan. Jika hasil kegiatan semakin mendekati sasaran, berarti makin tinggi efektivitasnya. Efektivitas merupakan unsur pokok untuk mencapai tujuan atau sasaran yang telah ditentukan di dalam setiap organisasi, kegiatan ataupun program. 


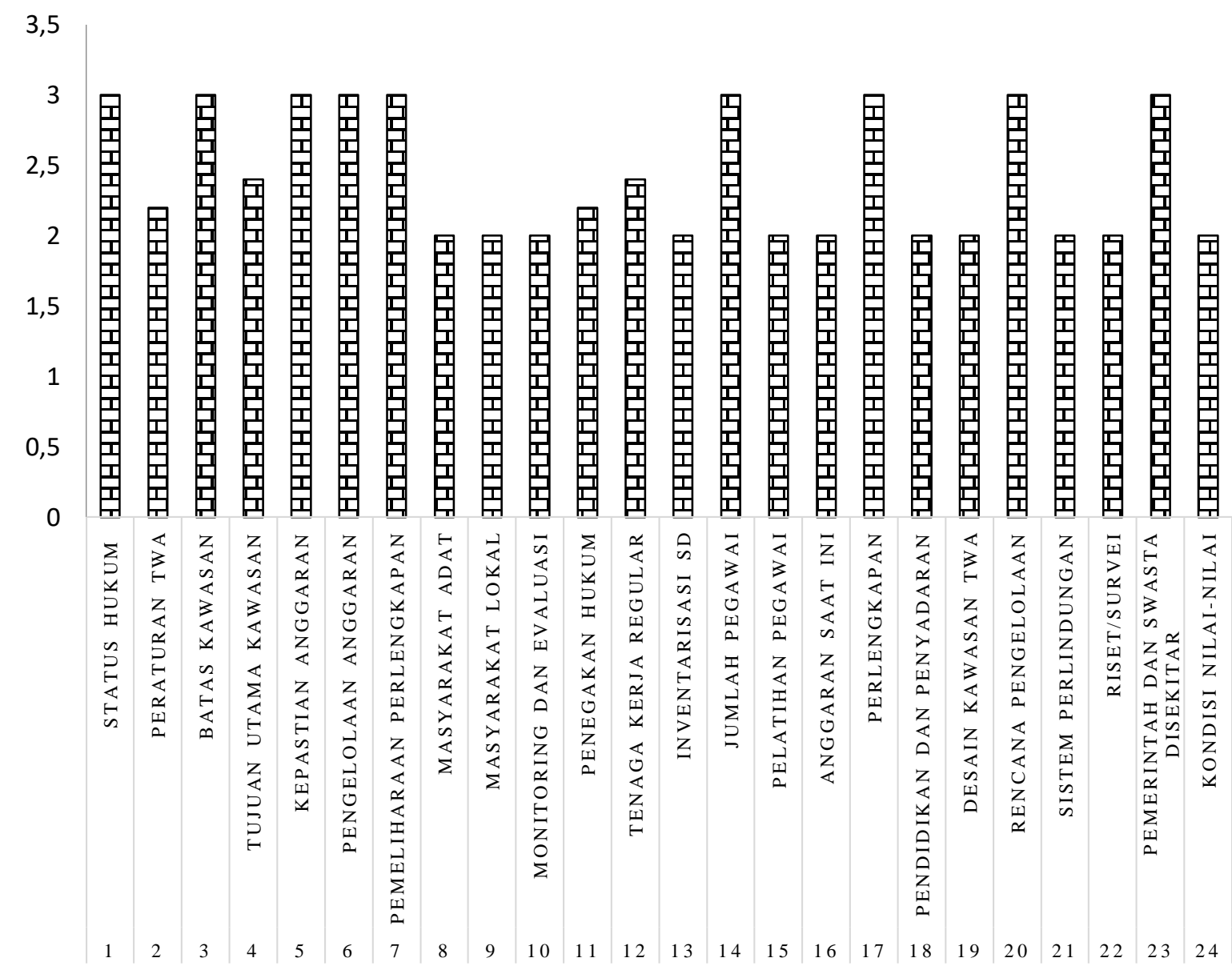

Gambar 1. Efektivitas Pengelolaan TWA Bukit Kaba

Gambar 1 menjelaskan berdasarkan metode METT, penelitian Efektivitas pengelolaan TWA Bukit Kaba melalui beberapa kriteria penilaian. Kriteria yang memperoleh skor tinggi diantaranya status hukum, peraturan kawasan konservasi dan pengukuhan batasan kawasan konservasi. Status hokum TWA Bukit Kaba dengan SK penunjukan yaitu SK. No.383/KptsII/1985 tanggal 27 Desember 1985, telah di tata batas secara definitive dan kemudian ditunjuk kembali dengan SK Menhut No.420/Kpts-II/1999 tanggal 15 juni 1999 dan Sk. No.3981/MenhutVII/KUH/2014 tangal 23 Mei 2014.

Bengkulu Peraturan yang mengatur dan mengendalikan penggunaan lahan dan kegiatan di kawasan konservasi khususnya di TWA Bukit Kaba ada beberapa diantaranya yaitu : UU No.5 tahun 1990 tentang konservasi sumberdaya hayati dan ekosistemnya, UU. No.41 tahun 1999 tentang kehutanan, PP No.28 tahun 2011 tentang pengelolaan kawasan suaka alam dan kawasan pelestarian alam dan UU No.18 tahun 2013 tentang pencegahan dan pemberantasan kerusakan hutan.

Batas kawasan Sudah disahkan melalui orientasi batas dan rekonstruksi batas kawasan pada tahun 2017 dilakukan proses rekonstruksi pada sebagian batas kawasan TWA Bukit Kaba. Penataan batas kawasan telah dilakukan pada tahun 1987/1988, dengan berita acara ditandatangani tanggal 30 Juni 1990 dan pengesahan tanggal 18 Maret 1992. Panjang batas TWA Bukit Kaba adalah $82.3 \mathrm{~km}$ yang ditandai dengan pemasangan 820 buah pal beton bertulang. Selain itu juga telah dipasang seng pengumuman sebanyak 410 buah dan seng penunjuk pal 820 buah. (Balai KSDA.2002).

Staf terlatih dan keahlian yang memadai tentunya tidak luput dari kegiatan 
pelatihan ataupun pengembangan ilmu pengetahuan tambahan dan sangat perlu dilakukannya kegiatan pelatihan sehingga kedepannya mampu mencapai tujuan keberlangsungan dan keberlanjutan bagi pengelola. Anggaran yang tersedia saat ini sudah mencukupi namun, untuk mencapai pengelolaan yang efektiv secara keseluruhan belum bias dikatakan cukup. Untuk kepastian anggaran disetiap tahunnya pemerintah telah menganggarkan sesuai dengan kebutuhan.

Kondisi nilai-nilai dari pada TWA Bukit Kaba ini sendiri secara tidak langsung mengalami penurunan disamping fungsi ekosistemnya yang terganggu, nilai etika dan buda pengunjung juga terkadang menunjukkan ketidak perhatian mereka terhadap lingkungan. Merujuk dari itulah ada bulan-bulan tertentu yang dijadikan masa istirahat TWA Bukit Kaba dengan di tutupnya akses masuk kawasan guna memperbaiki ekositem kawsan. Namun di samping itu juga kita sering kecolongan dimana jalur masuk TWA ini sendiri hamper disetiap Desa sekita kawasan TWA bias di akses tanpa sepengetahuan pengelola.

Survey lapangan memberikan dugaan bahwa secara keseluruhan dapat dikatakan kegiatan monitoring dan sosialisasi TWA masih perlu ditingkatkan. Monitoring dengan tujuan menjaga keutuhan kawasan masih belum seperti yang diharapkan. Terbukti pada beberapa lokasi telah terjadi perambahan dan terdeteksi oleh pihak yang berwenang setelah tanaman masyarakat telah berumur beberapa waktu bahkan mungkin telah siap panen. (BKSDA Bengkulu, 2010).

Tabel 1. Persentase Efektivitas Pengelolaan

\begin{tabular}{|c|c|c|c|}
\hline Aspek & Total Skor & Persentase $(\%)$ & Keterangan \\
\hline A. Konteks & 273 & 91 & Sangat Efektif \\
\hline B. Perencanaan & 580 & 73 & Efektif \\
\hline C. Proses & 247 & 82 & Sangat Efektif \\
\hline D. Output & 233 & 78 & Sangat Efektif \\
\hline E. Outcome & 533 & 76 & Sangat Efektif \\
\hline Rata-Rata & & 80 & Sangat Efektif \\
\hline
\end{tabular}

Tabel 1 menjelaskan tentang persentase Efektivitas pengelolaan TWA Bukit Kaba berdasarkan aspek pendukung yaitu berdasarkan konteks dimana memperoleh total skor $91 \%$ (Sangat Efektif), berdasarkan perencanaan mendapat total skor $73 \%$ (Efektif), berdasarkan proses mendapat total skor $82 \%$ (Sangat efektif), berdasarkan output $78 \%$ (Sangat efektif) dan outcome dengan total skor $76 \%$ (Sangat efektif). dengan perolehan persentase rata-rata $80 \%$ dari hasil penilaian Efektifita Pengelolaan untuk Taman Wisata Alam Bukit Kaba secara keseluruhan dinyatakan Sangat Efektif

Indonesia, pada tahun 2009 Taman Nasional Gede Pangrango melakukan penilaian Efektivitas menggunakan metode yang sama yaitu METT (Management Effetivenes Tracking Tools). Berdasarkan hasil METT didapat hasil sebesar $76 \%$ yang termasuk kedalam kategori Efektiv dalam pengelolaan secara keseluruhan. (KLHK, 2015)

Salah satu penyebab kurang maksimalnya pengelolaan TWA Bukit Kaba adalah tingginya gangguan terhadap keutuhan kawasan secara keseluruhan. Bentuk gangguan terhadap kawasan diantaranya adalah pemanfaatan lahan non procedural untuk pertanian dan perkebunan, penebangan kayu, dan perburuan satwa liar. Konsentrasi pengelolaan menjadi sangat terpecah antara penyelesaian permasalahan kawasan dengan peningkatan optimalisasi potensi 
kawasan. (Pedoman Penelitian KLHK, 2015).

\section{Perubahan Tutupan Lahan}

Pada tahun 2015-2016 terjadi perubahan yang signifikan dengan bertambahnya kelas penutupan lahan yaitu terbentuknya sawah/persawahan dengan pesentase bukaan sebanyak $31 \%$. ini tentunya sangant mepengaruhi kelas tutupan lahan lainnya seperti pertanian lahan kering bercampur semak mengalami penurunan sebesar $14 \%$ darai sebelumnya sebesar $44 \%$ menjadi $30 \%$. Pertanian lahan kering juga mengalami perubahan yang sama yaitu mengalami penurunan sebesar $14 \%$ darai sebelumnya sebesar $44 \%$ menjadi $30 \%$, diikuti dengan hutan lahan kering mengalami penurunan $1 \%$, semak belukar juga $1 \%$ dan tanah terbuka juga mengalami perubahan $1 \%$ dari jumlah persentase tahun 2014 dan 2015 yaitu $4 \%$.

Tabel 2. Perubahan Tutupan Lahan TWA Bukit Kaba dari Tahun 2014-2016

\begin{tabular}{lclll}
\hline \multirow{2}{*}{ Kelas Penutupan Lahan } & Kode Tutupan & \multicolumn{3}{c}{ Luasan (Ha)/tahun } \\
\cline { 3 - 5 } & Lahan & \multicolumn{1}{c}{2014} & 2015 & \multicolumn{1}{c}{2016} \\
\hline Hutan lahan kering & 2002 & 4481,8 & 4481,8 & 5005,7 \\
Semak Belukar & 2007 & 694,5 & 882,2 & 516,6 \\
Tanah Terbuka & 2014 & 320,7 & 133 & 186,3 \\
Pertanian Lahan Kering & 20091 & 5,2 & 5,2 & 5,2 \\
Pertanian Lahan Kering Bercampur Semak & 20092 & 9623,8 & 9606,9 & 9395,3 \\
Sawah/Persawahan & 20093 & - & 16,9 & 16,9 \\
\hline \multicolumn{1}{c}{ Luas TWA Bukit Kaba berdasarkan Data Tutupan Lahan } & 15126 & 15126 & 15126
\end{tabular}

Luas penutupan lahan pada tahun 2014 pada masing-masing kelas penutupan lahan berbeda-beda, pada tahun 2014 luas hutan lahan kering mencapai 4481,8 ha, di tahun 2015 tidak mengalami perubahan sama sekali sedangkan pada tahun 2016 terjadi penambahan sebanyak 523.9 ha dengan junlah perolehan sebesar 5005.7 Ha.

Pada kelas penutupan lahan semak belukar (kode 2007) di tahun 2014 mencapai 694,5 ha, ditahun berikutnya 2015 terjadi peningkatan yang signifikan dengan penambhan luasan sebanyak 187.7 ha dengan luasan 882.2 ha. Pada tahun 2016 mengalami pengurangan luasan yang juga signifikan melebihi angka penambhan di tahun sebelumnya yaitu sebesar 365,6 ha dari semula 882.2 ha menjadi $516.6 \mathrm{Ha}$.

Kelas penutupan lahan tanah terbuka (kode 2014), pada 2015 terjadi penurunan luasan sebanyak 187.7 ha menjadi 133 ha dengan luasan sebelumnya
320.7 ha di tahun 2014. Pada tahun 2016 mengalami penambahan luasan yang tidak terlalu signifikan yaitu sebesar 53.3 ha dari sebelumnya 133 ha menjadi 186.3 ha, tidak melebihi angka penambhan di tahun sebelumnya.

Pada lahan pertanian lahan kering (kode 20091) pada tahun ke tahun dari 2014, 2015 dan 2016 tidak mengalami peruhan baik itu penambhan maupun pengurangan (tetap) dengan luasan 5,2 ha. Tahun 2014 pertanian lahan kering bercampur semak (kode 20092) dengan luasan 9623,8 mengalami pengurangan luasan sebanyak 16,9 ha pada tahun 2015 menjadi 9606,9 ha. Namun pada tahun 2016 terjadi pengurangan luasan sebanyak 228.5 ha menjadi 9395.3 ha yang tidak begitu signifikan dengan luasan sebelumnya. pada tahun 2016 terdapat kelas penutupan lahan sawah/persawahan (kode 20093) dengan luasan 16,9 ha yang justru tidak ada pada tahun 2014 . 


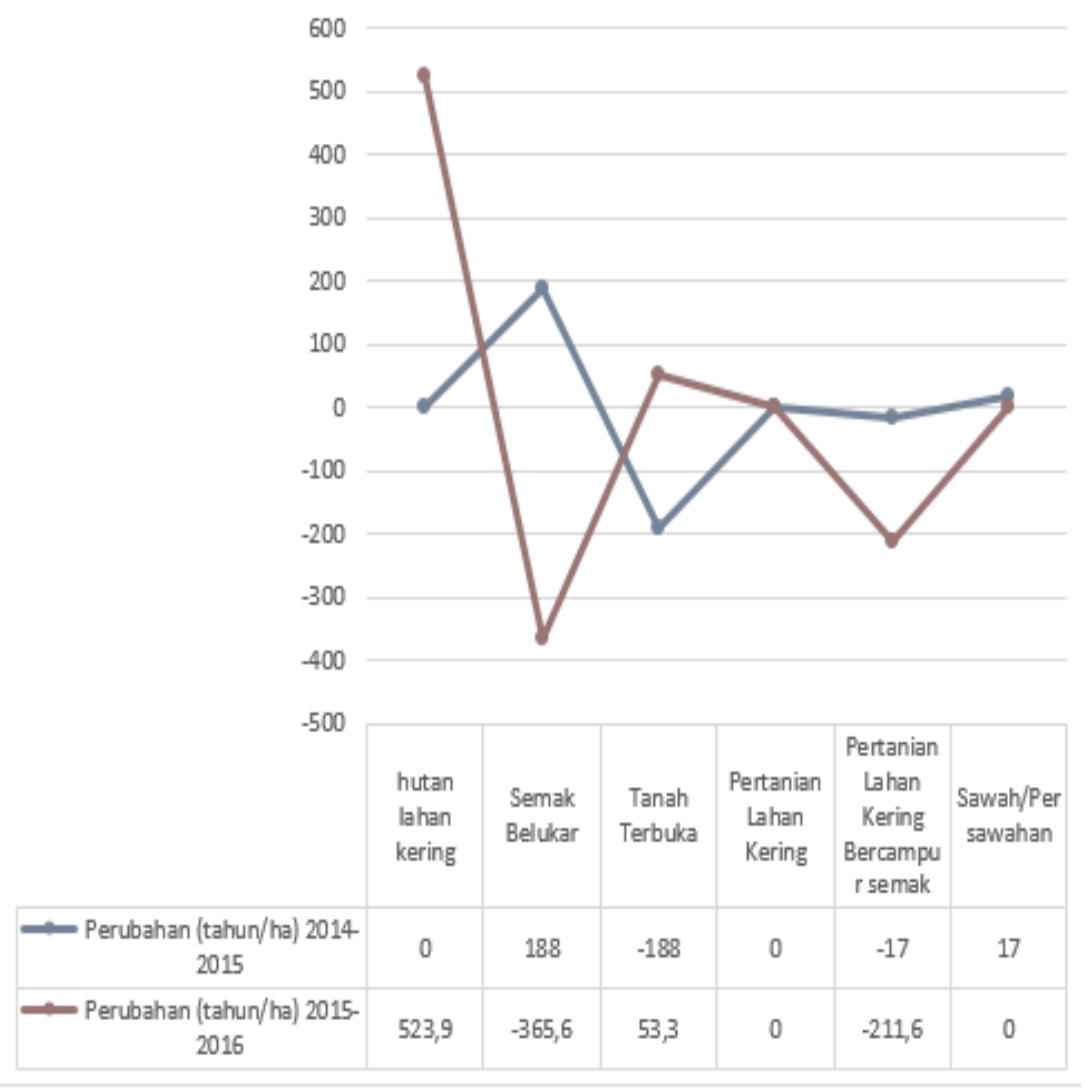

Gambar 2. Luas Perubahan Tutupan Lahan.

Gambar 2 menjelaskan luas perubahan tutupan lahan dari tahun 20142015 dan 2015-2016. Dari hasil tersebut dapat dilihat bahwa pada tahun 2014-2015 pada hutan lahan kering tidak terdapat perubahan baik itu penambahan maupun pengurangan. Pada tutupan semak belukar justru mengalami pertambahan luasan sebesar 188 ha diikuti dengan berkurangnya jumlah luasan pada tutupan lahan tanah terbuka sebanyak 188 Ha. Pada tutupan lahan pertanian lahan kering tidak mengalami perubahan baik penambahan maupun pengurangan justru sebaliknya pada tutupan pertanian lahan kering bercampur semak mengalami pengurangan luasan sebanyak 17 ha. Pada tutupan lahan sawah/persawahan mengalami penambahan sebanyak 17 ha pada tahun 2015 namun pada tahun 2014 sawah/persawaahan justru tidak ada.
Pada tahun 2015-2016 hutan lahan kering mengalami penambahan yang drastis yaitu sebesar 523,9 ha, diikuti semak belukar mengalami penurunan luasan sebanyak 365,6 ha, tanah terbuka justru mengalami pertambahan seluas 53,3 ha, namun pada tutupan lahan pertanian lahan kering tetap pada posisi awal 20142015 tidak mengalami perubahan baik penambahan maupun pengurangan, pertanian lahan kering bercampur semak mengalami pengurangn lagi sebanyak 211,6 ha, sebaliknya pada tutupan lahan sawah/persawahan tidak mengalami perubahan luasan.

Pada tahun 2015-2016 hutan lahan kering mengalami penambahan yang drastis yaitu sebesar 523,9 ha, diikuti semak belukar mengalami penurunan luasan sebanyak 365,6 ha, tanah terbuka justru mengalami pertambahan seluas 53,3 ha, namun pada tutupan lahan pertanian 
lahan kering tetap pada posisi awal 20142015 tidak mengalami perubahan baik penambahan maupun pengurangan, pertanian lahan kering bercampur semak mengalami pengurangn lagi sebanyak 211,6 ha, sebaliknya pada tutupan lahan sawah/persawahan tidak mengalami perubahan luasan.
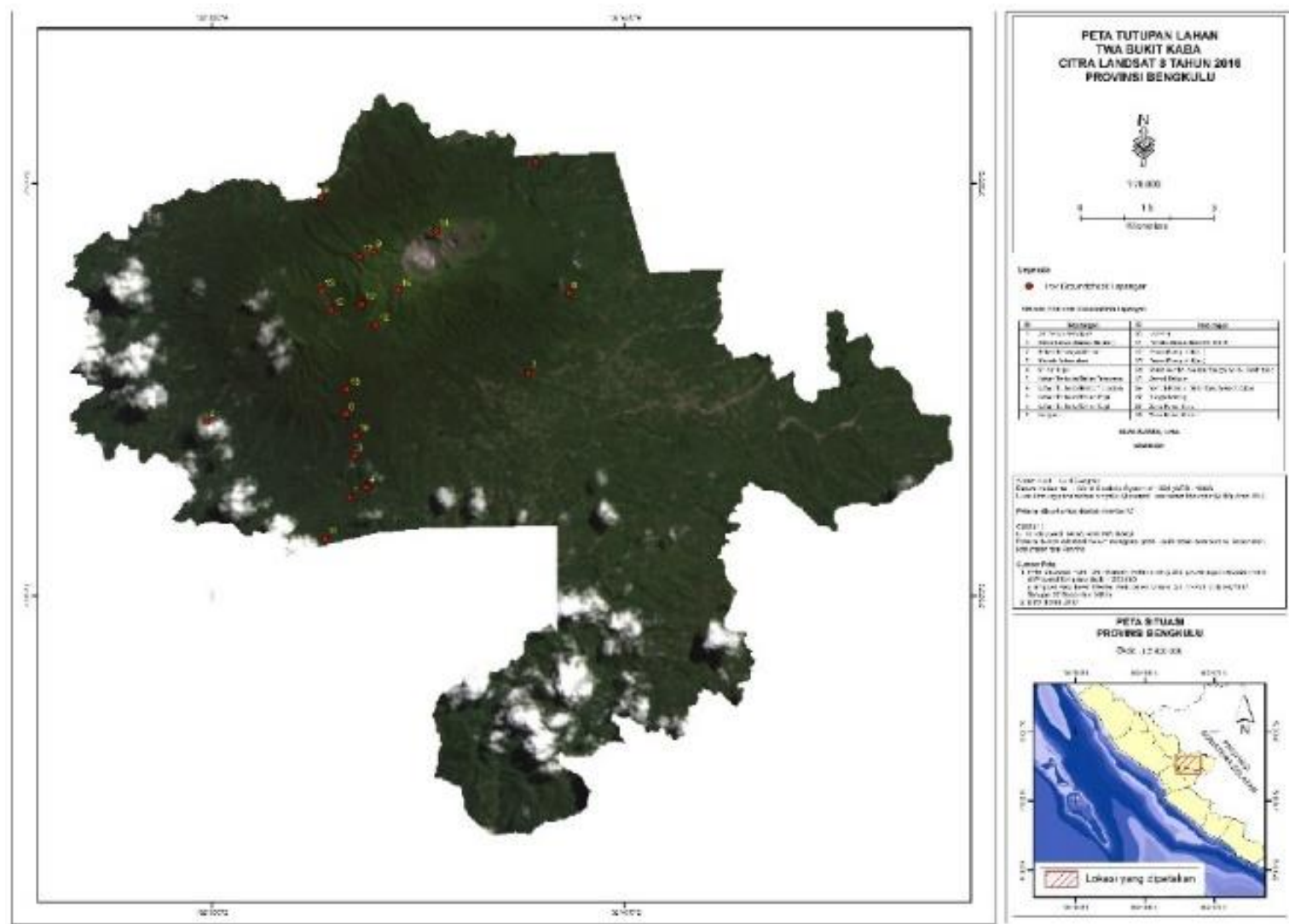

Gambar 3. Grouncheck Point

Gambar 3 menjelaskan tentang fakta dilapangan membuktikan bahwa telah terjadi perubahan kondisi fisik bentang alam dimana ekosistem asli berubah menjadi hamparan perkebunan kopi dan pertanian secara umum, pemukiman, dan fasilitas umum. Pembiaran terhadap aksi kejahatan konservasi yeng berupa mengerjakan, menggunakan atau menduduki kawasan hutan secara tidak sah, serta perambahan dipastikan berdampak pada makin merosotnya fungsi dan manfaat hutan yang berperan sebagai perlindungan wilayah sistem penyangga kehidupan, yang berakibat pada terancamnya keselamatan nyawa manusia secara masal.

Hasil Groundcheck Point di lapangan terdapat 20 titik point/koordinat pengambilan sample Groundcheck yang ditampilkan mulai dari 0-19 point. Untuk tipe-tipe penutupan lahan yang di cek diantaranya tipe semak belukar yang merupakan lahan yang ditubuhi oleh semak belukar/tambuhan rendah yang rapat. Tabel 2 di bawah ini akan menunjukan tentang kenampakan di lapangan dari hasil Groundcheck Point di TWA Bukit Kaba. 

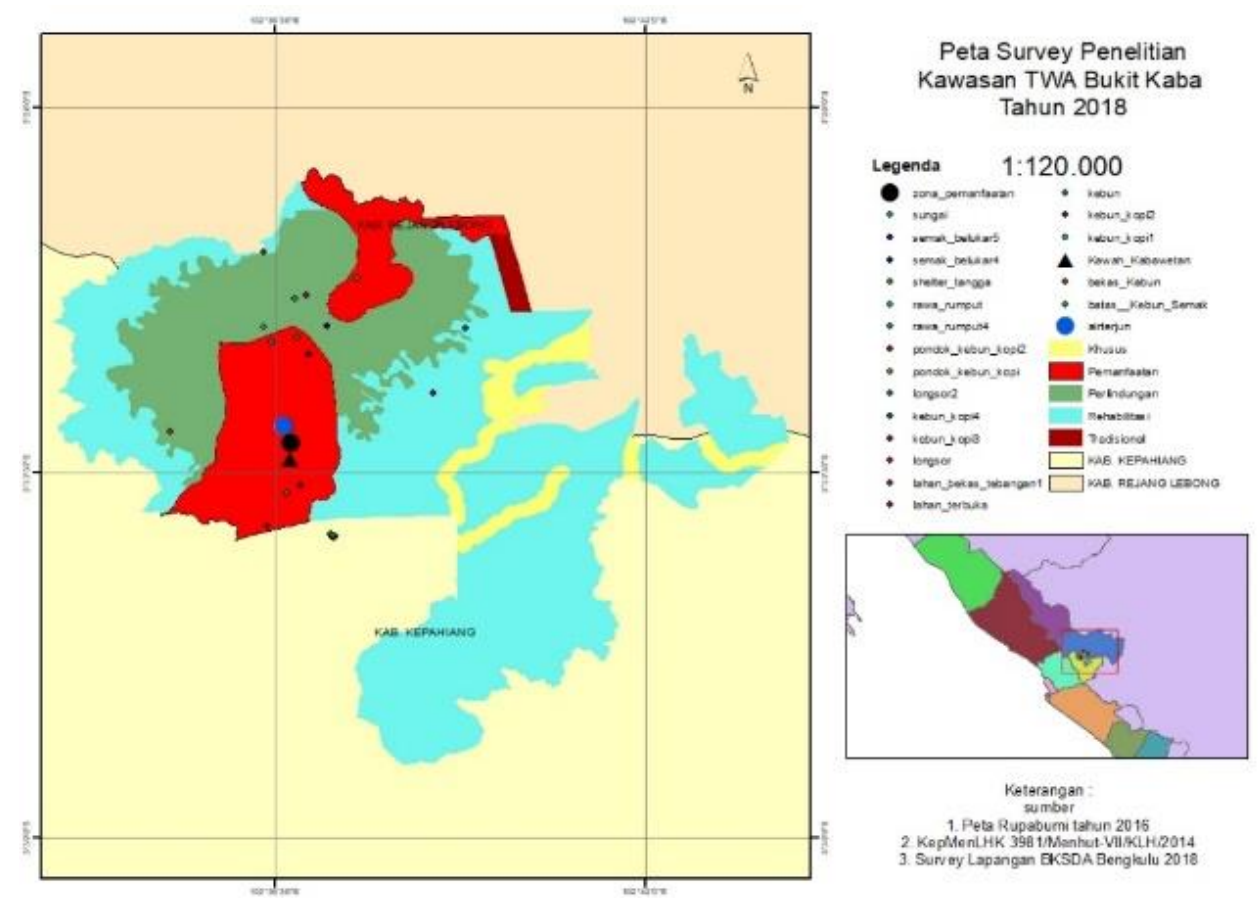

Gambar 4. Peta Survei Lapangan dan Groundcheck Point berdasarkan Zonasi Kawasan

Gambar 4 menjelaskan

Groundcheck Point pada tutupan lahan berdasarkan zona pengelolaan TWA Bukit Kaba. Adapun TWA Bukit Kaba dibagi dalam 5 zona/block pengelolaan yaitu blok pemanfatan ditandai dengan warna merah, blok khusus berwarna kuning, blok perlindungan warna hijau, blok rehabilitasi warna biru dan blok tradisional di tandai dengan warna cokelat.

Hasil Groundcheck Point tersebut terdapat 10 point berada pada zona/block pemanfaatan diantaranya terdapat kebun kopi, lahan terbuka, lahan bekas tebangan, kawah/sumber air panas dan air terjun. Pada zona/block perlindungan tersebar sebanyak 5 titik Groundceck diantaranya terdapat rawa dengan rumput yang hijau, semak belukar, sungai/badan sungai dan bekas longsoran. Pada zona/block rehabilitasi terdapat 3 titik Groundcheck yang terdiri dari kebun kopi dan lahan bekas tebangan.

\section{KESIMPULAN}

1. Kondisi Tutupan Lahan TWA Bukit Kaba Pada tahun 2014 terdapat 5 kelas tutupan lahan. Selanjutnya mengalami perubahan Pada tahun 2015-2016 dengan bertambahnya kelas penutupan lahan yaitu sawah/persawahan.

terbentuknya

2. Efektivitas Pengelolaan TWA Bukit Kaba berdasarkan Konteks Pengelolaan dimana memperoleh nilai $14 \%$, berdasarkan Perencanaan 34\%, berdasarkan Proses 13\%, berdasarkan Output $12 \%$ dan outcome sebanyak $27 \%$. Dari hasil tersebut dapat disimpulkan bahwa proses masing-masing konteks dalam penilaian efektivitas pengelolaan TWA Bukit Kaba sudah berjalan namun masih belum efektif dalam pengelolaan secara keseluruhan (perlu di tingkatkan lagi).

\section{DAFTAR PUSTAKA}

Adimihardja, K. 1993. Kebudayaan dan Lingkungan, Studi Bibliogrofhy. Ilham Jaya Bandung.

Arikunto, S. 2006. Prosedur Penelitian Suatu Pendekatan Praktik. Jakarta: PT. Rineka Cipta. 
Arief, A. 2001. Hutan dan Kehutanan. Kanisius. Yogyakarta

Asdep MLH Urusan Wilayah Sumatera. 2005. Suara Bumi, Edisi 3. Sumatera.

Balai KSDA Bengkulu. 2002. Profil Kawasan TWA Bukit KAba. Bengkulu

BSNI. 2010. "Klasifikasi Penutup Lahan". SNI :7645 Badan Standardisasi Nasional.

BSNI. 2010. "Kelas Penutupan Lahan Dalam Penafsiran Citra Optis Resolusi Seadang”. RSNI-1 Badan Standardisasi Nasional.

Erdeti, R. 2003. Analisis Faktor-faktor Yang Mempengaruhi Permintaan Emping Melinjo. Program Studi Sosial Ekonomi Pertanian Fakultas Pertanian Universitas Bengkulu. Bengkulu.

Fandeli, C. 2007. "Pengembangan Eekowisata di Kawasan Bukit Kaba Berbasis E-Konservasi.

Fandeli, C. 2002. Perencanaan Kepariwisataan Alam. Fakultas Kehutanan UGM, Yogyakarta.

Febrianti, F. 2000. Kondisi Sosial Ekonomi dan Perilaku Masyarakat Disekitar Hutan Lindung Ridu Hati Taba Penanjung Kabupaten Bengkulu Utara. Skripsi Jurusan Budidaya Hutan. Fakultas Pertanian.
Universitas bengkulu (tidak dipublikasikan)

Hutahayan, D. 2010. "Strategi Pengelolaan Kawasan Hutan TWA Bukit Kaba Dalam Mengatasi dampak Negatif Pembangunan Daerah". BKSDA. Bengkulu.

Puminda, A. 2015. "Perubahan Tutupan Lahan di Taman Nasional Bukit Barisan Selatan Provinsi Lampung". Departemen Konservasi Sumberdaya Hayati dan Ekowisata Fakultas Kehutanan. IPB. Bogor

Suraji, R. Basuki et All. .Menuju pengelolaan efektif kawasan konservasi parairan di indonesia : Metode efektivitas kawasan konservasi pesisir, pesisir pulaupulau kecil (E-KKP3K).

Undang-undang Republik Indonesia. 1990. Undang-undang Nomor 41 tahun 1990 tentang kehutanan. Jakarta.

Wardhana, D. 2015. Mengenal Metode Penilaian Efektivitas Pengelolaan Kawasan Konservasi. Artikel. http://ksdasul sel.org/kawasan/164mengenal-metode-penilaianefektivitas-pengelolaan-kawasankonservasi?showall $=1$. Diakses 8 maret 2015. 